\title{
京都市小中学生の身長体重同時分布 （昭和41年と51年との比較）
}

\author{
The Joint Distribution of Height and Weight Observed on School Children in \\ Kyoto City (Comparison of the Distribution in 1976 with That in 1966)
}

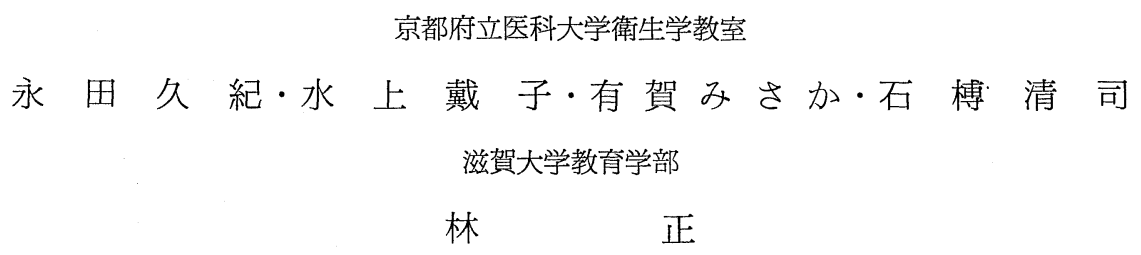

Hisanori Nagata, Taiko Mizukami, Misaka Aruga and Kiyoshi Ishigure

Department of Hygiene, Kyoto Prefectural University of Medicine, Kyoto

Tadashi Hayashi

School of Education, Shiga University, Otsu

On each group of boys or girls in every school year of primary schools and junior high schools in Kyoto city, the joint distribution of height and weight was investigated based on the data in April 1976, and the distribution was compared with that in 1966.

The arithmetical means and standard deviations of height and weight, the correlation coefficient between height and weight, and the regression coefficient of weight on height were calculated (Table 1). Besides, the median, 10th and 90th percentiles of weight distribution in every group of height (1 $\mathrm{cm}$ in width) were calculated to note the characteristics of the joint distribution more clearly (Fig. 1, Fig. 2, Table 2).

In every group of boys or girls in every school year, the arithmetical means of height and weight, and the standard deviation of weigth in 1976 were greater than those in 1966. But the differences between 1976 and 1966 were negligible as for the correlation between height and weight, and the regression coefficient of weight on height.

For boys in the school year from the second to sixth in the primary school, and for girls in the school year from the third to sixth in the primary school and in the first school year of the junior high school, the median, 10th and 90th percentiles of weight corresponding to the same height were almost the same in 1976 and in 1966, for every group of height.

For boys in the first school year of the primary school and for girls in the first and second school year of the primary school and in the third school year of the junior high school, 90th percentile of weight corresponding to the same height was greater in 1976 for relatively tall children. For boys in every school year of the junior high school, 90th percentile of weight corresponding to the same height was greater in 1976 for every group of height. However, for these groups of school children, the median and 10th percentile of weight corresponding to the same height were almost the same in both years.

For girls in the second grade school year of the junior high school, the median and 90th percentile of weight corresponding to the same height were greater in 1976 for relatively short children. The difference of the form of the joint distribution between 1976 and 1966 seemed to suggest the acceleration of growth since 1966. 
著者らは昭和41 (1966)年に京都市の市立小中学校の児 童生徒を対象として学年別男女別に身長体重同時分布を 調査した ${ }^{1 \text { 4) }}$ 。文部省の学校保健統計 ${ }^{5}$ そよると, 小中学 生の身長平均值, 体重平均值はその後む年々増加してい る。この 10 年間に身長平均値，体重平均值が増加したば かりでなく, 身長体重同時分布の型む変化したか否かが 問題となる。そこで昭和51(1976)年に，再び京都市の市 立小中学校の児童生徒を対象として学年別男女別に身長 体重同時分布を調查した。昭和 41 年と51年の身長体重同 時分布を比較した結果について報告する。

\section{I . 資料とその分析方法}

昭和51年の調査では京都市立小中学校のなかから，行 政区別学校規模別に約 $1 / 5$ の小中学校を抽出し, 抽出校 の児童生徒を被調査者とした。昭和 41 年の調査では約 $1 / 2$ 小中学校が抽出されていたので, 今回の被調査者 は昭和 41 年にくらべて, 学年によって約 $1 / 2$, あるいは $1 / 2$ 以下となったが (表 1 参照), 抽出校の 地域分布は両 年の調査でほぼ一致している。

身長, 体重は昭和 $41 ， 51$ 年ともに 4 月の定期健康乵断 時の測定值である。

昭和 51 年の資料は，昭和 41 年の資料の分析方法を参考 として，以下のように分析した。

(1) 学年別男女別に身長の平均值之標準偏差, 体重の 平均値, 中央値之標準偏差, 身長之体重との相関係数, 身長に対する体重の回帰係数を求めた。

(2) 学年別男女別に身長を $1 \mathrm{~cm}$ 間隔, 体重を $1 \mathrm{~kg}$ 間 隔に区分した身長体重同時分布表をつくり，との表から 各身長階級 (1 cm 幅) における体重の中央值, 10 パーセ ンタイル値（軽いほうから $10 \%$ に相当する人の体重, 以 後下位 $10 \%$ 体重值という), 90 パーセンタイル値（重い ほうから10\%に相当する人の体重，以後上位10\%体重値 という）を計算した。なお，偶然による変動をなるべく 少なくするために, 計算は $1 \mathrm{~cm}$ 幅の身長階級内の人数 が 30 人以上の場合に限った。昭和 51 年の調查では 41 年の 調查より被調查者が少数であったので, 身長階級別に体 重の中央值，下位 $10 \%$ 体重値，上位 $10 \%$ 体重值を求める ことのできた身長の範囲は昭和 51 年では 41 年にくらべて, 最大 $13 \mathrm{~cm}$ (中 3 男子：中学 3 年男子の略称, 以下同様 の略称を用いる), 最小 $1 \mathrm{~cm}$ (小 2 女子) せまくなった。

(3) 学年別男女別に, 身長階級別江求めた体重中央値, 下位 $10 \%$ 体重值，上位 $10 \%$ 体重值に最むよく適合する直 線（身長との関係を示す一次式）を最小 2 乗法によって 求めた。昭和 41 年の資料については以前にも一次式が一
応求められていたが，今回昭和51年の資料についてと全 く同一の方法で計算しなおした。

\section{II. 調 查 結 果}

表 1 は学年別男女別の身長の平均値, 標準偏差, 体重 の平均值, 標準偏差, 身長と体重との相関係数, 身長に 対する体重の回帰係数である。体重分布は正の歪みを呈 するので, 3)，体重分布の位置の代表値としては平均值 よりむ中央値がより適当と考えられるが，計算結果では， すべての学年の男女で, 体重の平均值と中央值との相違 が僅少であったので，表には平均值のみを記載した。

身長平均値, 体重平均值はすべての学年で男女ともに, 昭和51年の值が 41 年の值を有意に (1\% 水準) 上廻って いる。身長平均值の両年間の相違は絶対量でみても, (昭 和 51 年の值)/(昭和 41 年の值) の比でみても，男子では 中 2 , 中 3 , 女子では小 5 , 小 6 で大きい。体重平均値 の両年間の相違は絶対量でみると, 男子では中 1 以上, 女子では小 5 以上の各学年でそれぞれほぼ等しく, 他の 学年より大きいが, 両年の值の比は男子では中 1 , 中 2 , 女子では小 5 , 小 6 でとくに大きい。なお, 身長平均値 と体重平均値とからローレル指数を求めてみると, ほと んどの学年の男女で, 昭和 41 年の值と51年の值がほぼ等 しくなるが，中 1 以上の男子では昭和 51 年の值が 41 年の 值より大きくなっている。

身長の標準偏差には両年の值にほとんど差が認められ ないが，男子の中 3 ，女子の中 1 以上では昭和 51 年の值 のほうがやや小さい。体重の標準偏差はすべての学年で 男女ともに昭和51年の值のほうがやや大きい。なお，身 長, 体重ともに標準偏差の学年間男女間の大小関係は両 年でほぼ一致している。

身長と体重との相関係数には両年間に大きな相違は認 められない。男子の小 6 , 中 3 , 女子の小 4 , 中 1 以上 では両年の相関係数の差は $5 \%$ 以下の危険率で有意であ るが, 差の絶対量は小さい。なお，昭和 41 年の女子の場 合，中 2 以上では中 1 以下にくらべて相関係数がかなり 小さくなっていたが，乙の傾向は昭和51年ではさらに著 しくなっている。また，昭和51年では男子においてあ中 3 の相関係数が中 2 にくらべてかなり小さくなっている。 身長に対する体重の回帰係数にも昭和 51 年之 41 年との間 に大きな相違は認められない。

図 1 は男子, 図 2 は女子の学年別の身長体重同時分布 であるが，これらの図は以下の手順で作図されている。 $1 \mathrm{~cm}$ 幅の各身長階級で求めた下位 $10 \%$ 体重値, 上位 10 \%体重值はそれぞれほぼ一直線上にならんだので，てれ 
Table 1 Means and standard deviations of heights and weights, correlation coefficients between height and weight, and regression coefficients of weight on height

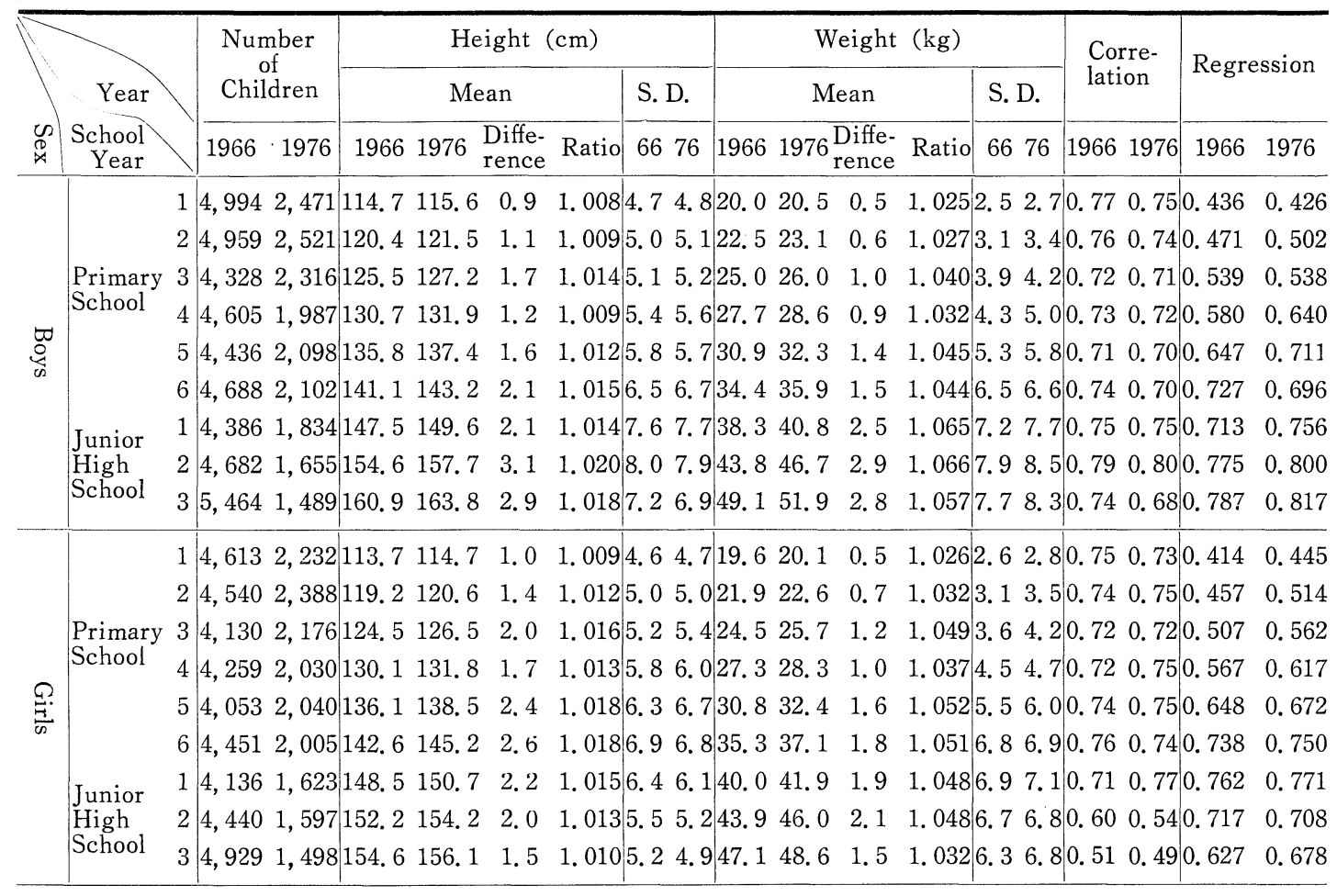

らの点に最もよく適合する直線を最小 2 乗法によって求 めた。下仙10\%体重值の直線への適合はきわめて良好で, 実際の計算值と直線上の期待值との相関係数は昭和 51 年 の中 3 女子で0.959であった以外はすべての場合に0.975 以上であった。上位 $10 \%$ 体重值の直線への適合は下位 10 \%体重值の場合ほど良好ではなかったが，実際の計算值 之直線上の期待值との相関係数は昭和 51 年の中 1 男子で 0.930 , 中 3 男子で 0.949 , 中 2 女子で 0.938 , 中 3 女子 で 0.941 , 昭和 41 年の小 4 男子で 0.939 であった以外は すべての場合に0.95以上であった。なお，上位 $10 \%$ 体重 值に二次式をあてはめても計算值と期待値との相関係数 はほとんど大きくならなかった。これらの下位10\%体重 值, 上位 $10 \%$ 体重值に適合させた $2 つ の$ 直線と, $\bar{x}-$ $1.282 \mathrm{SD}$ ( $\bar{x}$ は身長平均値, SD は身長の標準偏差)の身 長を示す直線, $\bar{x}+1.282 \mathrm{SD}$ の身長を示す直線で囲まれ たのが図示された梯形である。

身長はほぼ正規分布をするので $\bar{x}-1.282 \mathrm{SD} \sim \bar{x}+$ 1. $282 \mathrm{SD}$ の身長範囲には全対象の約 $80 \%$ が包含される とみなしうる ${ }^{6)}$ 。また, 各身長階級の下位 $10 \%$ 体重值と 上位 $10 \%$ 体重值との間にはそれぞれの対象の $80 \%$ が包含
される。したがって図示した梯形内には全対象の約 $64 \%$ が包含され，との梯形の型は身長体重同時分布の特徵を ある程度適確に示していると考えるととができる。図に は身長体重同時分布の型をより明確にするために, 各身 長階級の体重中央值に適合した直線(最小 2 乗法による) を併記した。直線の適合はきわめて良好で, すべての場 合に実際の計算值と直線上の期待値との相関は 0.98 以上 であった。

この図で体重の分布範囲を示すのに，平均値と標準偏 差を用いないで，体重の中央値，下位10\%体重值，上位 $10 \%$ 体重值を用いたのは，昭和41年の調査 $\left.{ }^{1 \sim 4}\right)$ で身長別 の体重の分布型がかなり著しい正の歪みを呈し, この歪 みは体重の立方根を変数として用いても消失しないこと, また, 体重の分散の大きさが身長階級によりかなり著し く相違し, 身長が高い階級ほど体重の分散が大きいとと が判明していたからである。なお，表 2 亿図 1 ，2 の基礎 となった数值，すなわち $\bar{x} \pm 1.282 \mathrm{SD}$ 亿相当する身長 並びにこれらの身長に対応する体重中央值，下位 $10 \%$ 体 重值, 上位 $10 \%$ 体重值（いずれも適合させた直線上の期 待值）を示した。 

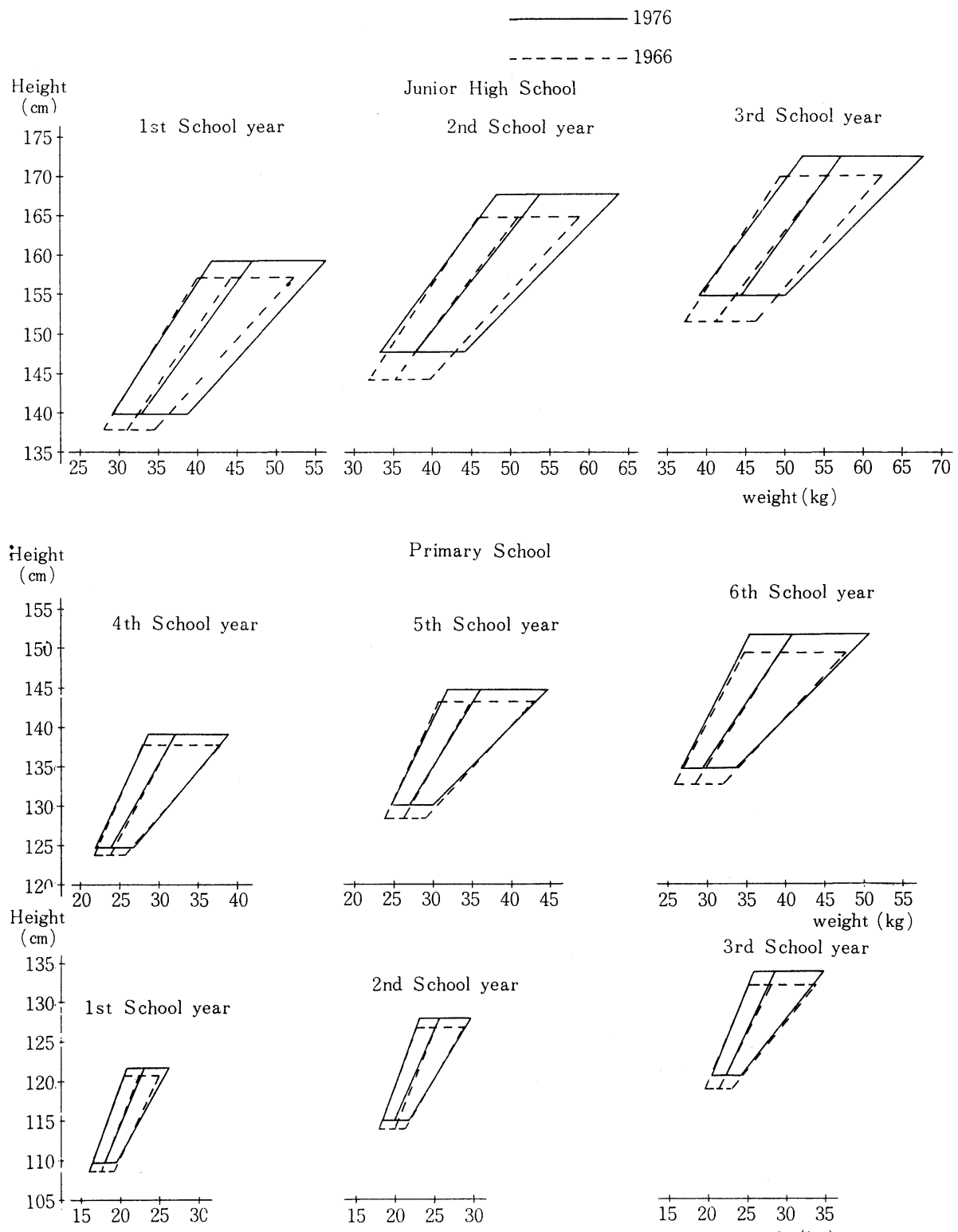

6th School year
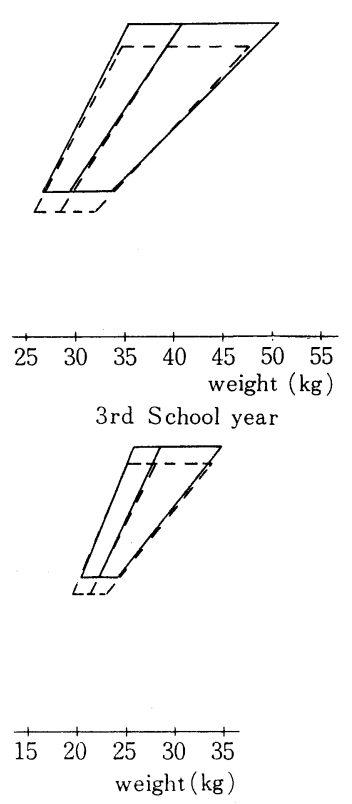

Fig. 1 Joint distribution of height and weight (Boys)

身長体重同時分布の型は学年により, 男女によって異 なっているが，乙こではむっぱら同学年同性の身長体重 同時分布の昭和51年と41年との異同について検討する。 学年により, あるいは男女によって程度に差はあるが, すべての学年で男女ともに，昭和 51 年の身長の範囲は 41 年より高いほうに移動している。

男子の小 2 小 6 , 女子の小 $3 \sim$ 中 1 では体重中央値,
下位10\%体重値，上位10\%体重值に適合させた直線の傾 斜，並びに各身長に対する体重中央值，下位 $10 \%$ 体重值， 上位10\%体重值が両年でほとんど一致している。すなわ ち, 雨年の身長体重同時分布は位置は多少移動している が，型は類似している。

小 1 男子並びに女子の小 1 , 小 2 , 中 3 では体重中央 値, 下位10\%体重值に適合させた直線の傾斜, 並びに各 


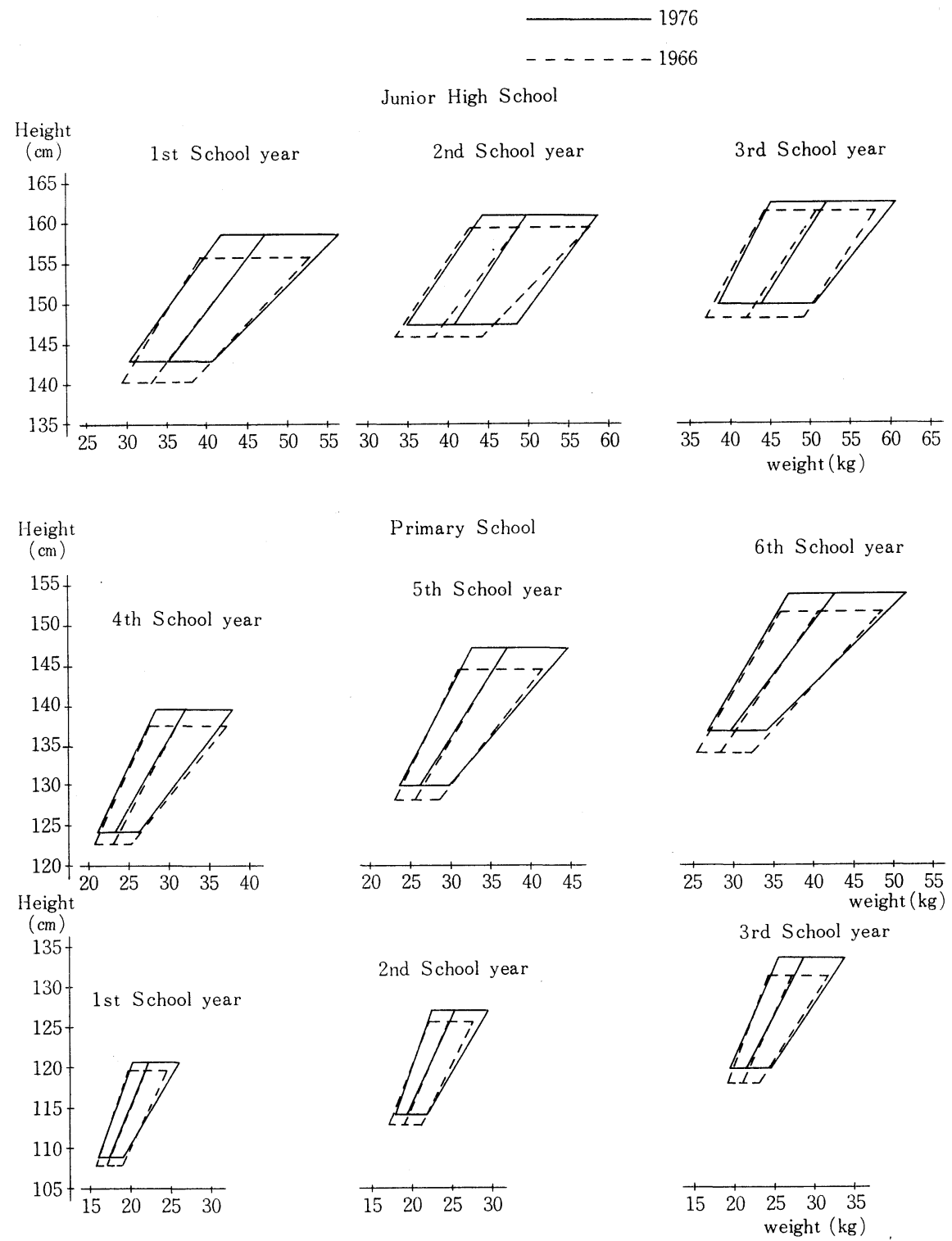

Fig. 2 Joint distribution of height and weight (Girls)

身長に対する体重中央值，下位10\%体重值は両年でよく 一致しているが，昭和51年では41年にくらべて，身長の 増加に対する上位10\%体重值の増加の割合がやや大きく， 身長の高い階級の上位10\%体重值がやや大きくなってい る。上位 $10 \%$ 体重値は，とくに身長が平均值からかなり へだたった身長階級では，被調查数が少ないために偶然 によって変動しやすい。したがって上位10\%体重值に適 合させた直線の傾斜に認められた両年間の差は単なる抽
出変動の結果にすぎないかむしれない（值線の傾斜の標 準誤差が不明であるので検定ができない)。しかし，小 学校低学年の小 1 男子, 小 1 , 小 2 女子で同様の傾向が 認められている点を考慮すると, 少なくとも小学校低学 年では, 実際に, 身長体重同時分布に上述の上うな変化 がおてったとみなしてあよいであろう。

中 1 , 中 2 , 中 3 男子では, 体重中央值, 下位 $10 \%$ 体 重值, 上位 $10 \%$ 体重值に適合させた直線の傾斜, 並びに 
Table 2 Heights correspond to $\bar{x} \pm 1.282$ SD, and medians of weight, 10 and 90 percentile weights correspond to these heights

\begin{tabular}{|c|c|c|c|c|c|c|c|c|c|c|}
\hline & \multirow[b]{2}{*}{$\begin{array}{l}\text { School } \\
\text { Year }\end{array}$} & \multicolumn{2}{|c|}{$\begin{array}{l}\text { Height (A) } \\
(\mathrm{cm}) \text { corres- } \\
\text { pond to } \bar{x}- \\
1.282 \mathrm{SD}\end{array}$} & \multirow{2}{*}{$\begin{array}{l}10 \text { percen- } \\
\text { tile weight } \\
\text { (kg) corres- } \\
\text { pond to } \\
\text { Height (A) } \\
1966197 \mathrm{o}\end{array}$} & \multirow{2}{*}{$\begin{array}{l}\text { Median of } \\
\text { weight (kg) } \\
\text { correspond } \\
\text { to Height } \\
\text { (A) } \\
19661976\end{array}$} & \multirow{2}{*}{$\begin{array}{l}90 \text { percen- } \\
\text { tile weight } \\
(\mathrm{kg}) \text { corres- } \\
\text { pond to } \\
\text { Height } \quad(\mathrm{A}) \\
19661976\end{array}$} & \multirow{2}{*}{$\begin{array}{l}\text { Height (B) } \\
(\mathrm{cm}) \text { corres- } \\
\text { pond to } \bar{x}+ \\
1.282 \mathrm{SD} \\
19661976\end{array}$} & \multirow{2}{*}{$\begin{array}{l}10 \text { percen- } \\
\text { tile weight } \\
\text { (kg) corres- } \\
\text { pond to } \\
\text { Height } \quad(B) \\
19661976\end{array}$} & \multirow{2}{*}{$\begin{array}{l}\text { Median of } \\
\text { weight (kg) } \\
\text { correspond } \\
\text { to Height } \\
\text { (B) } \\
19661976\end{array}$} & \multirow{2}{*}{$\begin{array}{l}90 \text { percen- } \\
\text { tile weight } \\
\text { (kg) corres- } \\
\text { pond to } \\
\text { Height } \quad \text { (B) } \\
19661976\end{array}$} \\
\hline & & 1966 & 1976 & & & & & & & \\
\hline \multirow{9}{*}{ 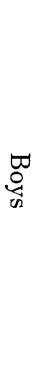 } & \multirow{6}{*}{$\begin{array}{l}\text { Primary } \\
\text { School }\end{array}$} & 1108.6 & 109.5 & 16.116 .6 & 718.0 & 19.319 .5 & 120.7121 .7 & 20.8 & 322.9 & 25.026 .1 \\
\hline & & 2114.0 & 15.0 & 17.918 .4 & 19.520 .0 & 21.321 .8 & 126.8128 .0 & 22.923 .2 & 25.125 .8 & 28.829 .9 \\
\hline & & 3118.9 & 120.6 & 19.720 .4 & 21.522 .3 & 23.124 .2 & 132.1133 .9 & 25.325 .8 & 27.928 .8 & 33.834 .9 \\
\hline & & 4123.7 & 124.7 & 21.722 .0 & 23.724 .1 & 25.826 .6 & 137.6139 .1 & 27.928 .7 & 31.032 .2 & 38.038 .8 \\
\hline & & 5128.5 & 30.0 & 23.924 .5 & 26.126 .9 & 28.830 .0 & 143.2144 .8 & 330.931 .9 & 34.736 .1 & 42.944 .8 \\
\hline & & 6132.7 & 34.7 & 25.926 .7 & 28.429 .5 & 31.833 .7 & 149.5151 .8 & 34.735 .5 & 39.440 .8 & 47.750 .7 \\
\hline & \multirow{3}{*}{$\begin{array}{l}\text { Junior } \\
\text { High } \\
\text { School }\end{array}$} & 1137.8 & 139.8 & 28.029 .2 & 31.032 .6 & 34.538 .7 & 157.5 159.4 & 40.041 .9 & 44.547 .1 & 52.556 .5 \\
\hline & & 2144.3 & 147.6 & 31.933 .1 & 35.337 .7 & $39.7^{\circ} 44.2$ & 164.9167 .8 & \begin{tabular}{l|ll}
3 & 45.8 & 48.3
\end{tabular} & 51.253 .9 & 59.063 .8 \\
\hline & & 3151.7 & 154.9 & 37.339 .1 & 41.144 .2 & 46.450 .1 & 170.1172 .7 & 49.752 .5 & 55.757 .5 & 62.967 .8 \\
\hline \multirow{9}{*}{$\frac{\Omega}{\infty}$} & \multirow{6}{*}{$\begin{array}{l}\text { Primary } \\
\text { School }\end{array}$} & 1107.8 & 08.8 & 15.616 .0 & 17.117 .6 & 9.1 & 0.7 & 720.3 & 21.922 .4 & 24.6 \\
\hline & & 2112.8 & 114.1 & 17.217 .8 & 18.919 .4 & 21.021 .8 & 125.6127 .0 & 22.022 .5 & 24.425 .3 & 27.629 .5 \\
\hline & & 3117.9 & 119.6 & 19.219 .5 & 21.121 .6 & 23.224 .6 & 131.2133 .5 & 24.525 .7 & 27.228 .9 & 31.933 .9 \\
\hline & & 4122.7 & 124.2 & 20.821 .3 & 23.023 .3 & 25.426 .5 & 137.4139 .5 & 27.528 .4 & 31.032 .2 & 37.337 .9 \\
\hline & & 5128.0 & 129.9 & 23.123 .7 & 25.626 .4 & 28.629 .8 & 144.2147 .0 & 31.032 .7 & 35.137 .2 & 41.544 .9 \\
\hline & & 6133.8 & 136.5 & 25.627 .0 & 28.629 .8 & 32.434 .2 & 151.5153 .8 & 36.237 .2 & 41.043 .3 & 49.052 .0 \\
\hline & \multirow{3}{*}{$\begin{array}{l}\text { Junior } \\
\text { High } \\
\text { School }\end{array}$} & 1140.3 & 142.9 & 29.430 .4 & 33.235 .3 & 38.140 .7 & 155.7158 .5 & 39.241 .7 & 44.947 .5 & 52.956 .4 \\
\hline & & 2145.1 & 147.5 & 33.434 .8 & 37.941 .0 & 44.348 .6 & 159.3160 .9 & 42.744 .2 & $48.7 \quad 49.9$ & 57.658 .7 \\
\hline & & 3148.0 & 149.8 & 37.038 .5 & 42.044 .0 & 49.350 .6 & 161.2162 .4 & 44.345 .2 & 50.652 .3 & 58.460 .6 \\
\hline
\end{tabular}

各身長に対する体重中央値，下位10\%体重值には両年間 に大きな相違は認められなかったが，上位10\%体重值は すべての身長階級で昭和51年のほうが大きくなっている。 例数が比較的に多い平均值に近い身長階級では, 上位 10 \%体重値が偶然によって大きく変動する可能性は小さい こと, 中 1 , 中 2 , 中 3 男子で同様の傾向が認められた とと, さきに示したように中 1 中 3 男子のみで, 身長 平均值と体重平均值から求めたローレル指数が昭和 51 年 のほうが大きくなっていたととなどを考慮すると, 中 1 〜中 3 男子では, 実際に, 体重がかなり重い者の比率が すべての身長階級で多少増加したとみなすべきであろう。 中 2 女子の身長体重同時分布の両年間の相違はやや特 異的である。すなわち昭和 51 年では 41 年にくらべて, 身 長が比較的に低い身長階級の体重中央値, 上位 $10 \%$ 体重 值が大きく，身長の増加に対する体重中央值，上位 $10 \%$ 体重値の增加の割合が小さくなっている。両年間の身長 体重同時分布の相違は抽出変動による見加上のものに すぎないかむしれないが，相違の程度はかなり著しく, 抽出変動のみで説明するのは無理と思われる。

\section{III. 考察}

1) すべての学年で男女ともに，昭和51年の身長平均 值は昭和41年の值を有意に上廻っていた。身長平均値の 年次的な増加傾向の原因の探究は本論文の範囲をてえる 問題であるが, 調查結果から身長平均值の年次的な増加 傾向が一部はいわゆる発育促進現象》, すなわち第 2 次 成長の発現あるいは終了の時期が年秢的に早くなった結 果であるととを示唆する二，三の所見が得られた。すな わち, a ) 平均身長の学年間の相違をみると (表 1 ), 男 子では昭和 $51 ， 41$ 年ともに中 1 と中 2 の間が最む大きい が, 中 1 と中 2 との差は昭和 51 年のほうが大きく, 中 2 と中 3 との差は 41 年のほうが大きい。女子では昭和 41 年 では小 5 と小 6 との間が最も大きいが， 51 年では小 4 と 小 5 の間, 小 5 と小 6 の間の差が等しく, また, 小 6 と 中 1 , 中 1 と中 2 , 中 2 と中 3 との平均身長の差はすべ て昭和51年のほうが小さくなっている。b ）児童生徒の 身長の標準偏差は一般に成長の最盛期に大きくなるとと が指摘されているが8), 中 3 男子, 中 1 中 3 女子の昭 
和51年の身長の標準偏差は41年より小さくなっている。 c ）昭和 41 年の調查で身長と体重との相関が中 2 , 中 3 女子では他の学年の女子あるいは男子の場合にくらべて かなり小さいととが認められた9)。すなわち身長と体重 との相関は成長最盛期が終了にちかづいた年齢では小さ くなるとみなしうる。昭和 51 年の調査結果では中 2 , 中 3 女子, とくに中 2 女子の身長と体重との相関が 41 年よ りさらに小さく，また男子であ中 3 の相関が 41 年よりか なり小さくなっている。d) 中 2 女子の身長体重同時分 布の昭和 51 年と 41 年との相違はやや特異的で, 昭和51年 では41年にくらべて，身長の比較的低い身長階級の体重 中央値，上位 $10 \%$ 体重值が大きく，身長の増加に対する 体重中央值, 上位 $10 \%$ 体重值の増加の割合が小さくなっ ていたが，乙の所見は要するに，昭和51年の身長体重同 時分布の型は，41年当時よりむ，成人の身長体重同時分 布の型（たとえば中 3 女子の型）により近似したととを 示している。

2) すべての学年で男女とむに, 昭和51年の体重の平 均值, 標準偏差は41年の值を上迴り, 一見, 昭和51年で は41年にくらべて肥満傾向の児童生徒が増加したような, あるいは体重のちらばりが大きくなったような感じをう ける。しかし, 身長別の体重中央値, 下位10\%体重值, 上 位 $10 \%$ 体重值を求めて身長体重同時分布を検討した結果, 男子の小 2 小 6 , 女子の小 3 中 1 では両年の身長体 重同時分布にほとんど相違がなく，昭和51年で 41 年にく らべて体重の平均值, 標準偏差が大きくなっていたのは, 両年間の身長平均值の相違にとむなう二次的な結果にす ぎないととが判明した。また，小 1 男子，小 1 , 小 2 , 中 3 女子では身長の比較的に高い身長階級で, 中 1 中 3 男 子ではすべての身長階級で昭和51年の上位 $10 \%$ 体重值が 41年の值を上迴っていたが，乙れらの場合にも各身長に 対する体重中央值は両年の值がほとんど等しく, 各身長 階級の体重中央值以下の体重分布は10年間でほとんど変 化していないととが判明した。身長体重同時分布にもと づいて，いわゆる身長別標準体重を求めることが多いが, 以上の結果加判断すると, 中 2 女子を除く都市小中学 生については, 昭和 41 年の身長別の標準体重を昭和 51 年 にそのまま採用してあ差支えないといいうる（適用身長 範囲は多少異なるが)。ただ標準体重としては身長別の 平均体重を用いることが多いが, 平均値は少数の過体重 者のために体重分布の最頻值, 中央値よりかなり重いほ うに偏る傾向があるので, 出来うれば身長別の体重の中 央值あるいは最頻值を標準体重とするととがのぞましい。 なお，中 2 女子については，昭和51年では 41 年にくら
べて身長の比較的低い身長階級の体重中央値，上位 $10 \%$ 体重值が大きいととが認められ，しかむこの身長体重同 時分布の型の変化は発育促進現象の一つのあらわ机之推 測された。したがって身長別標準体重む昭和51年では 41 年とは別のあのと採用するほうが合理的であろう。しか し, 身長の低い身長階級においてす, 体重中央値の両年 間の相違はそれほど大きくないので，標準体重として身 長別の体重の中央值あるいは最頻値を採用していれば, 両年の身長別標準体重に大きな差は認められないであろ う。

3）以上, 昭和 51 年と 41 年との身長体重同時分布の型 の異同について論じてきたが，議論はすべて， $\bar{x} \pm 1.282$ SD の範囲の身長の者の下位 $10 \%$ 体重値, 上位 $10 \%$ 体重 值にあとづいてすすめられてきた。したがって上述の議 論加ら、いわゆるるい瘦児, あるいは肥満児の頻度の10,11) 両年間の相違は推測するととは妥当でなかろう。この問 題には別の検討が必要である。

$$
\mathrm{N} \text {.まとめ }
$$

京都市公立小中学校の児童生徒を対象とし, 昭和51年 4 月の定期健康診断時の身長, 体重測定值を用いて, 学 年別男女別に身長体重同時分布を調査した。昭和 41 年の 身長体重同時分布と比較して以下の所見を得た。

1) 身長平均値, 体重の平均値, 標準偏差は, すべて の学年で男女ともに, 昭和 51 年の值が 41 年の值を上迴っ ていた。

2) 身長と体重との相関係数，身長に対する体重の回 䚻係数には昭和 51 年の值と 41 年の值との間に大きな相違 が羿められなかった。

3) $\bar{x} \pm 1.282 \mathrm{SD}(\bar{x}$ は身長平均値, SD は身長の標準 偏差）の身長を示す直線と身長別の下位10\%体重值（体 重の10パーセンタイル值), 上位 $10 \%$ 体重值（体重の90 パーセンタイル值）にそれぞれ適合させた直線から梯形 を作図し，乙れに体重中央值に適合させた直線を併記し て両年の身長体重同時分布を比較した。

すべての学年で男女とむに昭和 51 年の身長範囲は 41 年 より高いほうに移動していたが, 男子の小 2 小 6 , 女 子の小 3 中 1 では, 両年の身長体重同時分布の型はほ ぼ一致し, 小 1 男子, 小 1 , 小 2 , 中 3 女子でも, 各身 長階級で, 体重中央值以下の体重分布は両年でほぼ一致 していた。

中 2 女子の身長体重同時分布の昭和 51 年と 41 年との相 違はやや特異的であったが，乙の相違は発育促進の結果 と推測された。この他にす発育促進を示唆する三, 三の 
所見が得られた。

資料は京都市学校保健会から提供された。付記して感 謝の意を表する。

\section{文献}

1) 永田久紀, 林 正：都市小中学生の身長別体重分 布, 医学々生物学, 74, 166-171 (1967).

2) 永田久紀, 林 正: 京都市学童の身長別体重表, 健康教室, 197集, 57-63 (1967).

3) 永田久紀, 林 正: 都市学童の身長別体重分布の 検討, 日衛誌，22，370-375 (1967).

4) 永田久紀, 林 正: 京都市中学生の身長別体重表, 健康教室, 203集, 25-28 (1967).

5）文部省大臣官房調查統計課：学校保健統計調查報告 書, 昭和47年度 (1974).

6) Armitage, P.: Statistical methods in medical res- earch, p. 458-459, Blackwell Scientific Publications, Oxford and Edinburgh, (1971).

7) 工藤陽子, 他: 身長の最大発育年齢からみたわが国 における発育促進現象の推移, 日衛誌, 31, 378-385 (1976).

8）西川捨己: 京都府下学童・生徒の体格の変移につい て, 日衛誌，13，876-881 (1959).

9) Nagata, H., and Hayashi, T.: Interrelations among Height, Weight, Chest Girth and Sitting Height Observed on School Children in Kyoto City. 日衛 誌, 22, 571-577 (1967).

16）永田久紀, 林 正: 京都市学童における過体重児 童の頻度, 学校保健研究, 9, 234-239 (1967).

11）永田久紀, 林 正: 京都市中学生に㧍ける過体重 生徒の頻度, 学校保健研究, 9, 293-296 (1967).

（受付 1976年11月27日） 